\title{
Thyroid Gland Follicular Carcinoma, Widely Invasive
}

National Cancer Institute

\section{Source}

National Cancer Institute. Thyroid Gland Follicular Carcinoma, Widely Invasive. NCI

Thesaurus. Code C156123.

A follicular carcinoma of the thyroid gland with extension into surrounding thyroid or extrathyroid tissues. 